\title{
SIMULATION OF INCREASED NITROGEN DEPOSITION TO A MONTANE FOREST ECOSYSTEM: PARTITIONING OF THE ADDED ${ }^{15} \mathrm{~N}$
}

\author{
P. SCHLEPPI ${ }^{1}$, I. BUCHER-WALLIN ${ }^{2}$, R. SIEGWOLF ${ }^{2}$, M. SAURER $^{2}$, N. MULLER $^{1}$ and \\ J.B. BUCHER ${ }^{1}$ \\ ${ }^{1}$ Swiss Federal Institute for Forest, Snow and Landscape Research, CH-8903 Birmensdorf, \\ ${ }^{2}$ Paul Scherrer Institute, CH-5232 Villigen, Switzerland
}

(Received 25 September 1998; accepted 25 February 1999)

\begin{abstract}
Nitrogen (N) was added over two years to a spruce-dominated (Picea abies) montane forest at Alptal, central Switzerland. A solution of ammonium nitrate $\left(\mathrm{NH}_{4} \mathrm{NO}_{3}\right)$ was frequently sprinkled on the forest floor $\left(1500 \mathrm{~m}^{2}\right)$ to simulate an additional input of $30 \mathrm{~kg} \mathrm{~N} \mathrm{ha}^{-1} \mathrm{yr}^{-1}$ over the ambient $12 \mathrm{~kg}$ bulk inorganic $\mathrm{N}$ deposition. The added nitrogen was labelled with ${ }^{15} \mathrm{NH}_{4}{ }^{15} \mathrm{NO}_{3}$ during the first year. Results are compared to a control plot.

Neither the trees nor the ground vegetation showed any increase in their $\mathrm{N}$ content. Only $4.1 \%$ of $\mathrm{N}$ in the ground vegetation came from the $\mathrm{N}$ addition. Current-year needles contained $11 \mathrm{mg} \mathrm{N} \mathrm{g}^{-1}$ dry weight, of which only $2 \%$ was from labelled $\mathrm{N}$; older needles had approximately half as much ${ }^{15} \mathrm{~N}$. The uptake from the treatment was therefore very small. Redistribution of $\mathrm{N}$ also took place in the trunks: 1 to 2-year-old wood contained $0.7 \%$ labelled $\mathrm{N}$, tree rings dating back 3 to 14 years contained $0.4 \%$.

Altogether, the above-ground vegetation took up $12 \%$ of the labelled N. Most ${ }^{15} \mathrm{~N}$ was recovered in the soil: $13 \%$ in litter and roots, $63 \%$ in the sieved soil. Nitrate leaching accounted for $10 \%$. Factors thought to be influencing $\mathrm{N}$ uptake are discussed in relation to plant use of $\mathrm{N}$ and soil conditions.
\end{abstract}

Key words: nitrogen deposition, montane forest, Picea abies, N-15 isotope, nitrate leaching

\section{Introduction}

Deposition of ammonium $\left(\mathrm{NH}_{4}^{+}\right)$and nitrate $\left(\mathrm{NO}_{3}{ }^{-}\right)$in natural or semi-natural ecosystems has increased as a consequence of the emission of inorganic nitrogen $(\mathrm{N})$ by human activities (Galloway, 1995). This supplementary $\mathrm{N}$ causes unintentional eutrophication of normally $\mathrm{N}$-limited systems, like most forests in temperate climates. Effects of such emissions on the $\mathrm{N}$ cycle of coniferous stands can be studied by experiments which manipulate the deposition rates (e.g. NITREX project: Wright \& Rasmussen, 1998). Effects on the vegetation, soil and water depend on the partitioning of deposited $\mathrm{N}$ between the different ecosystem compartments. This question has been addressed by supplementing ambient or manipulated throughfall with ${ }^{15} \mathrm{~N}$ (Buchmann et al., 1996; Tietema et al., 1998; Nadelhoffer et al., 1998 a, b). However, these experiments were conducted on podzol-like soils at altitudes below $700 \mathrm{~m}$. Along the northern range of the Alps, coniferous forests often grow on gleyic soils developed on Flysch parent material. This paper reports on effects of simulated increased $\mathrm{N}$ deposition to such a montane forest.

Water, Air, and Soil Pollution 116: 129-134, 1999.

(C) 1999 Kluwer Academic Publishers. Printed in the Netherlands. 


\section{Material and Methods}

\subsection{SITE AND TREATMENTS}

The experimental forest site is located in the valley of Alptal, central Switzerland, at an altitude of $1200 \mathrm{~m}$. The soils are umbric Gleysols with a west aspect and a slope of $20 \%$. The climate is cool and wet: $6^{\circ} \mathrm{C}$ average temperature and $2300 \mathrm{~mm}$ precipitation $\mathrm{yr}^{-1}$. The bulk deposition of inorganic $\mathrm{N}$ is $12 \mathrm{~kg} \mathrm{ha}^{-1} \mathrm{yr}^{-1}$ equally divided between $\mathrm{NO}_{3}^{-}$and $\mathrm{NH}_{4}{ }^{+}$(Schleppi et al., 1998 b).

The tree species are predominantly Norway spruce (Picea abies (L.) Karst) with $15 \%$ silver fir (Abies alba Miller). The canopy is relatively open; the leaf area index is 3.8 and the basal area $41 \mathrm{~m}^{2} \mathrm{ha}^{-1}$, despite the age of the trees (up to 250 years).

The vegetation and humus types of the Gleysols are closely linked to the microtopography and therefore to the water regime of the site (Schleppi et al., $1998 \mathrm{~b}$ ). Three different plant associations can be found (Muller, 1997): Vaccinium spp. (L.) shrubs grow on acidified mounds, along with the trees; the nutrient richer, wet depressions carry a graminoid community (in canopy gaps) or a Caltha palustris (L.) and Petasites alba ((L.) Gaertner) community (in the shade).

The experimental plots (approximately $1500 \mathrm{~m}^{2}$ each) were two small catchments from which water runoff was monitored (Schleppi et al., $1998 \mathrm{~b}$ ). Forty rotating sprinklers (1.5 $\mathrm{m}$ above ground) irrigated each plot, one with a $\mathrm{NH}_{4} \mathrm{NO}_{3}$ solution and the other (control) with water (Schleppi et al., 1998 a). The treatment was applied during precipitation events using water collected on a polyethylene sheet $\left(300 \mathrm{~m}^{2}\right)$ spread outside the forest. These frequent small additions (approximately 200 per year) simulated a deposition increase of $30 \mathrm{~kg} \mathrm{ha}^{-1} \mathrm{yr}^{-1}$. During the winter, the automatic irrigation was replaced by the occasional application of a concentrated $\mathrm{NH}_{4} \mathrm{NO}_{3}$ solution on the snow with a backpack-sprayer.

During the first year of treatment, between April 1995 and March 1996, the $\mathrm{NH}_{4} \mathrm{NO}_{3}$ was enriched with $1400 \% 0 \delta{ }^{15} \mathrm{NH}_{4}{ }^{15} \mathrm{NO}_{3}$. $\mathrm{N}$ isotopes were analysed with an elemental analyser (Carlo Erba, Fisons, Italy) coupled to an isotope-ratio mass-spectrometer (delta $\mathrm{S}$, Finnigan, Germany). The ${ }^{15} \mathrm{~N}$ enrichments were calculated as the $\delta{ }^{15} \mathrm{~N}$ values of the treated plot minus those of the control.

\subsection{VEGETATION}

Twigs were taken from the 7th whorl of five dominant trees per plot in December 1996. They were partitioned into the most recent five age classes. After drying, needles and twigs were separated and ground. The biomass of needles, twigs and branches was estimated using the measured leaf area index and allometric relations verified with a completely dissected branch from the middle of the crown. The ${ }^{15} \mathrm{~N}$ content of needles older than 5 years was estimated by extrapolation while an interpolation between twigs and trunk was made for the branches.

Wood cores were collected in the spring of 1997 from 8 and 5 spruce trees in the control and treated plots respectively. The following annual rings were separated: $1^{\text {st }}+2^{\text {nd }}$ (formed during and after the labelling), $3^{\text {rd }}-6^{\text {th }}, 7^{\text {th }}-10^{\text {th }}$ and $11^{\text {th }}-14^{\text {th }}$. In total, these samples represented about half of the sapwood. Analyses of total $\mathrm{N}$ and ${ }^{15} \mathrm{~N}$ were performed on dried, ground samples. Tree heights and diameters, bark weights, ring widths and core densities were used to estimate bark and wood biomass. 
The 10 most frequent species from the ground vegetation were sampled in August 1995 and 1996 for $\mathrm{N}$ and ${ }^{15} \mathrm{~N}$ analyses of their aboveground tissues. Weights and soil coverage of five individuals were used to estimate the biomass of herbs (Muller, 1997). Graminoids were harvested from five small quadrats $(10 \times 10 \mathrm{~cm})$.

\subsection{SOIL AND WATER}

Soil cores (30 cm deep) were taken in the spring of 1997 on an 8 x $8 \mathrm{~m}$ grid. They were separated into their horizons, dried, ground in a mortar and sieved. Organic material $>2$ $\mathrm{mm}$ was considered as the fraction "litter and roots". Prior to analysis, samples were proportionally bulked within each of four soil types defined according to their morphology and humus form.

Runoff water was sampled proportionally (1 aliquot every 200 1). Weekly bulked samples were analysed for $\mathrm{NO}_{3}{ }^{-}$and $\mathrm{NH}_{4}{ }^{+}$by ion chromatography and by flow injection, respectively. ${ }^{15} \mathrm{~N}$ was analysed according to Downs et al. (1998): after concentration of quarterly pooled samples over exchange resins, anions and cations were eluted separately and $\mathrm{NO}_{3}{ }^{-}$was reduced to $\mathrm{NH}_{4}{ }^{+}$with Devarda's alloy. $\mathrm{NH}_{4}{ }^{+}$was converted to $\mathrm{NH}_{3}$ and captured in fibreglass filters enclosed in teflon membranes. The filters were analysed by mass spectrometry.

\section{Results and discussion}

\subsection{VEgETATION}

The $\mathrm{NH}_{4} \mathrm{NO}_{3}$ treatment induced no detectable increase in the $\mathrm{N}$ content of the spruce trees or ground vegetation (Figure 1; see also Schleppi et al., 1999). The $\mathrm{N}$ content of the needles remained slightly deficient. Twigs and needles were similar in their ${ }^{15} \mathrm{~N}$ content: $2 \%$ of the $\mathrm{N}$ was labelled in the current-year tissues, while this specific labelling amounted to $1.1 \%$ in older twigs and needles. Because of this evident mobility, the applied $\mathrm{N}$ was not restricted to growing tissues but also diluted into the larger biomass already present before treatment.

Bark and wood contained on average $0.6 \%$ labelled N. ${ }^{15} \mathrm{~N}$ enrichment in the bark was higher than in the wood formed during or after labelling (rings 1+2, Figure 1c). Older wood also contained an appreciable amount of labelled N. Nadelhoffer et al. (1998 b) found a comparable incorporation of ${ }^{15} \mathrm{~N}$ into 3 to 5 -year-old wood of mature conifers. Our analysis of even older wood shows that this migration includes, without any significant decline, at least 14 annual rings. A large part of the pre-existing sapwood, if not all, is thus homogeneously labelled.

In the ground vegetation, Poa trivialis had a high ${ }^{15} \mathrm{~N}$ enrichment during labelling, but much less a year later (Figure 1d). By contrast, Vaccinium plants took up almost no ${ }^{15} \mathrm{~N}$ in 1995 but in 1996 both new and older shoots were labelled. Other species had an intermediate behaviour between P. trivialis and Vaccinium spp. With $4.1 \%$, the specific labelling of $\mathrm{N}$ was higher in the ground vegetation than in the trees. 

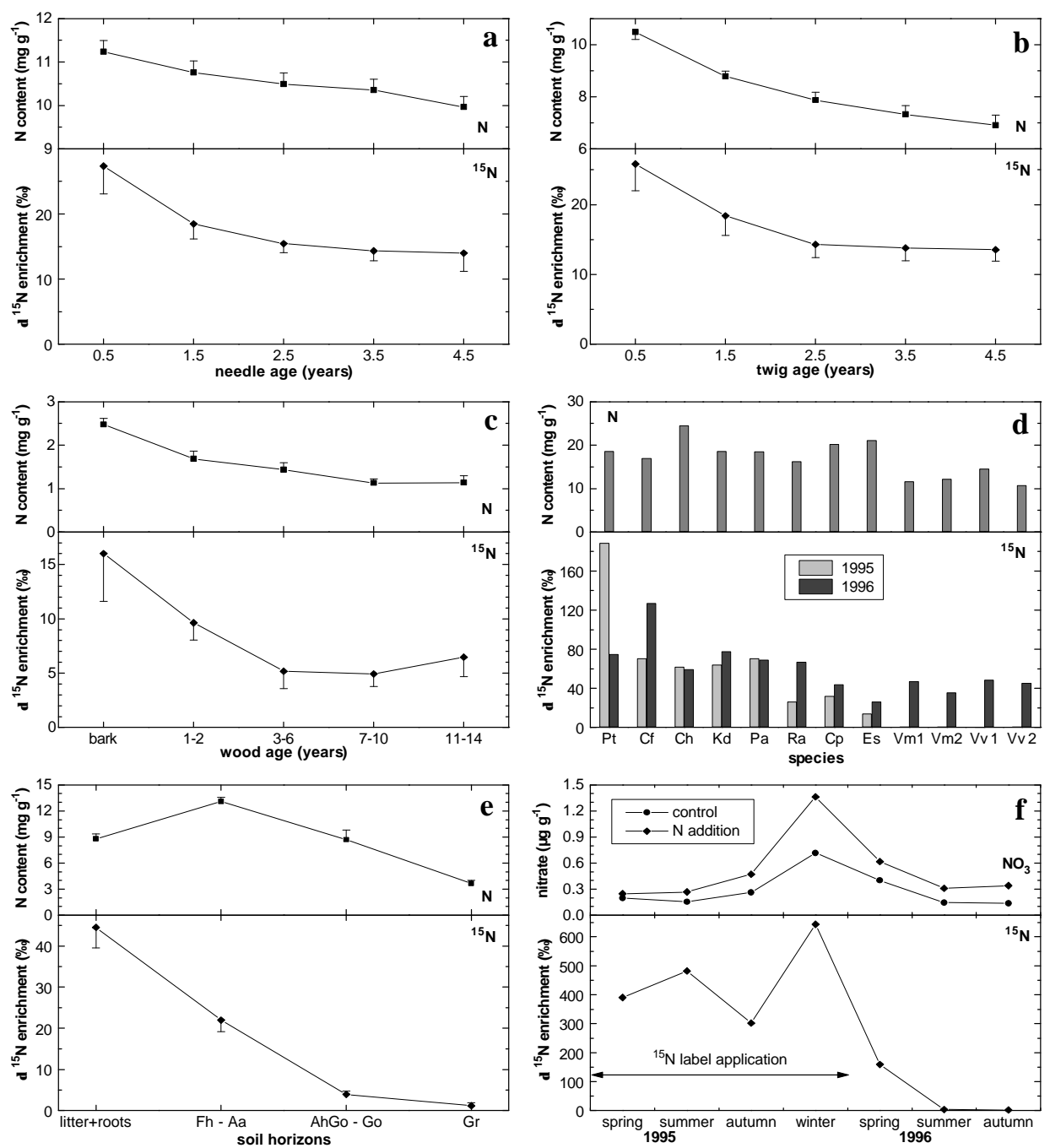

Fig. 1. $\mathrm{N}$ contents and ${ }^{15} \mathrm{~N}$ enrichments of different ecosystem pools and fluxes after the addition of $30 \mathrm{~kg} \mathrm{~N}$ $\mathrm{ha}^{-1}$ as $\mathrm{NH}_{4} \mathrm{NO}_{3}$ with a $\delta{ }^{15} \mathrm{~N}$ value of $1400 \%$. a: Picea abies needles, b: twigs, c: trunks, d: ground vegetation, e: soil, f: nitrate in runoff water. Bars denote standard errors where available. Species abbreviations: $\mathrm{Pt}=$ Poa trivialis, $\mathrm{Cf}=$ Carex ferruginea, $\mathrm{Ch}=$ Chaerophyllum hirsutum, $\mathrm{Kd}=$ Knautia dipsacifolia, $\mathrm{Pa}=$ Petasites alba, $\mathrm{Ra}=$ Ranunculus aconitifolius, $\mathrm{Cp}=$ Caltha palustris, $\mathrm{Es}=$ Equisetum sylvaticum, $\mathrm{Vm}=$ Vaccinium myrtillus, $\mathrm{Vv}=$ V. vitis-ideae $(1=$ current-year, $2=$ previous-years tissues $)$

\subsection{SOIL AND WATER}

There were no important differences between soil subtypes, so their results were pooled (Figure 1e). The strongest labelling was found in the "litter and roots" fraction. In the sieved soil, the total $\mathrm{N}$ content and especially the ${ }^{15} \mathrm{~N}$ labelling decreased markedly down the soil profile. This corresponds to chemical analyses which showed that the addition did not increase the $\mathrm{NH}_{4}{ }^{+}$or $\mathrm{NO}_{3}{ }^{-}$concentrations below the $10 \mathrm{~cm}$ depth (Hagedorn et al., 1997). Our findings thus contrast with the downward migration of ${ }^{15} \mathrm{~N}$ 
from ${ }^{15} \mathrm{NH}_{4}$ and especially from ${ }^{15} \mathrm{NO}_{3}$ reported by Buchmann et al. (1996), but this is probably due to the low permeability of the gley horizon at Alptal.

Ammonium in runoff was enriched by about $300 \% \delta^{15} \mathrm{~N}$, but was found only in negligible amounts. Nitrate leaching from the treated plot was almost double that of the control (Figure 1f), whereas it had been equal during the pre-treatment year (Schleppi et al., $1998 \mathrm{~b}$ ). Highest rates of leaching were observed during the winter of 1996, as snowmelt generated high runoffs together with high concentrations. The ${ }^{15} \mathrm{~N}$ labelling of $\mathrm{NO}_{3}{ }^{-}$was high throughout the year of label application and then declined to a few $\delta \%$ o within 3 months (spring to summer 1996). During the year of tracer application, the amount of labelled $\mathrm{N}$ leached as $\mathrm{NO}_{3}^{-}$was $2.8 \mathrm{~kg} \mathrm{ha}^{-1}$, close to the increase measured by chemical analyses $\left(+3.2 \mathrm{~kg} \mathrm{~N}^{-1}\right)$. This indicates that most of the additional $\mathrm{NO}_{3}{ }^{-}$ leaching was coming directly from the treatment, without isotopic dilution due to exchange processes in the soil. This by-passing is in good agreement with previous conclusions (Schleppi et al., 1998 b) that $\mathrm{NO}_{3}{ }^{-}$leaching from a Gleysol, as present at Alptal, is at least partly hydrologically driven (preferential flow through soil macropores) and therefore not sufficient proof that the ecosystem is $\mathrm{N}$-saturated.

\section{3. ${ }^{15} \mathrm{~N}$ BUDGET}

As measured by the acetylene inhibition method, denitrification increased from 1.7 to $2.9 \mathrm{~kg} \mathrm{~N} \mathrm{ha}^{-1} \mathrm{yr}^{-1}$ (Mohn, 1999), corresponding to $4 \%$ of the $\mathrm{N}$ addition not recovered as ${ }^{15} \mathrm{~N}$. On the other hand, there may be an overestimation of the recovery because the soil samples were taken at the end of winter and therefore included some litter from the already sampled ground vegetation. Considering these possible sources of error and all measurement uncertainties (Table I), the total recovery rate was close to $100 \%$.

Most ${ }^{15} \mathrm{~N}(63 \%)$ was retained in the soil, especially in its upper horizon. All pools had a relative labelling within the range observed in comparable European (Buchmann et al., 1996; Tietema et al., 1998) and North-American (Nadelhoffer et al., 1998 a, b) studies on coniferous stands. In our experiment, however, the ratios between vegetation and soil pools (especially trees / upper soil) were unusually low.

Table I

Partitioning of the added, ${ }^{15} \mathrm{~N}$ labelled nitrogen; pool sizes as dry matter, runoff flux as water.

\begin{tabular}{|c|c|c|c|c|c|}
\hline \multirow[b]{2}{*}{ pool } & \multirow{2}{*}{$\begin{array}{l}\text { pool size } \\
\left(\mathrm{kg} \mathrm{m}^{-2}\right)\end{array}$} & \multirow{2}{*}{$\begin{array}{l}\text { N content } \\
\left(\mathrm{g} \mathrm{kg}^{-1}\right)\end{array}$} & \multirow{2}{*}{$\begin{array}{l}\mathrm{N} \text { pool } \\
\left(\mathrm{g} \mathrm{m}^{-2}\right)\end{array}$} & \multicolumn{2}{|c|}{${ }^{15} \mathrm{~N}$ labelling $(\%)$} \\
\hline & & & & specific $^{1}$ & relative $^{2}$ \\
\hline needles & 1.30 & 8.8 & 11.4 & 1.2 & $5 \pm 2$ \\
\hline sapwood + bark & 13.7 & 1.4 & 19 & 0.6 & $3 \pm 1$ \\
\hline ground vegetation & 0.20 & 18.1 & 3.6 & 4.1 & $5 \pm 2$ \\
\hline litter + roots & 2.03 & 7.6 & 15.4 & 2.5 & $13 \pm 2$ \\
\hline upper soil & 6.23 & 13.7 & 83 & 1.5 & $42 \pm 9$ \\
\hline lower soil & 80.1 & 4.9 & 392 & 0.16 & $21 \pm 5$ \\
\hline runoff & 3600 & 0.0005 & 1.6 & 18 & $10 \pm 1$ \\
\hline total recovery & & & & & $99 \pm 13$ \\
\hline
\end{tabular}

${ }^{1}$ labelled $\mathrm{N} /$ total $\mathrm{N}$ content of the given pool or flux

2 labelled $\mathrm{N}$ in the pool or flux / added $\mathrm{N}$ amount, \pm standard error (based on data for the soil pools; conservative estimates by rules of error propagation for the vegetation and runoff)

Several factors probably explain the rather small $\mathrm{N}$-uptake by the vegetation. All plants analysed were perennial species and therefore rely partly on tissue reserves for 
their $\mathrm{N}$ nutrition. Internal recycling was especially evident for the woody plants (trees, Vaccinium shrubs). Ecological factors other than $\mathrm{N}$ are probably also limiting plant and root growth at Alptal, especially $\mathrm{P}$ and anaerobic soil conditions (Schleppi et al., 1998 b). These factors may hinder the uptake of $\mathrm{N}$, or at least delay it as already observed on trees resampled the second year after labelling (Tietema et al., 1998). In comparison with other ${ }^{15} \mathrm{~N}$ studies, the altitude of our site also reduces the vegetation period, hence the time of active nutrient uptake. Further, the availability of $\mathrm{N}$ in the soil solution was increased only in the upper few centimeters of the solum (Hagedorn et al., 1997). As already stated by these authors, this can be explained by (1) a partial denitrification and leaching of the added nitrate and (2) an effective fixation of the added ammonium by the clay-rich soil.

\section{Conclusion}

$\mathrm{N}$ added as $\mathrm{NH}_{4} \mathrm{NO}_{3}$ to the throughfall was mainly retained in the soil of the Alptal forest. The amount taken up by the vegetation was relatively low, but could be explained by site characteristics. The ecosystem was leaking part of the deposited $\mathrm{N}$ as nitrate in runoff water. Even if this apparent $\mathrm{N}$ saturation was probably hydrologically driven, it represents a long-term threat for the water quality which should be considered in calculations and discussions of critical loads of $\mathrm{N}$.

\section{Acknowledgement}

This study, as part of the European project NITREX, was partly financed by the Swiss Federal Office of Science and Education, Bern. It was run in collaboration with the Institute of Terrestrial Ecology of the ETH Zurich (Prof. Flühler). Technical assistance and English corrections were provided by D. Tarjan.

\section{References}

Buchmann, N., Gebauer, G., Schulze, E. D.: 1996, Biogeochem. 33, 1-23.

Downs, M. R., Michener, R. H., Fry, B., Nadelhoffer, K. J.: 1999, Environ. Monit. Assess., in press.

Galloway J. N.: 1995, Water Air Soil Pollut. 85, 15-24.

Hagedorn, F., Schleppi, P., Bucher, J. B.: 1997, Mitt. Dtsch. Bodenkundl. Ges. 85, 241-244.

Mohn, J.: 1999, Thesis, Univ. of Zurich.

Muller, N.: 1997, Thesis 12388, ETH Zurich.

Nadelhoffer, K. J., Downs, M. R., Fry, B., Magill, A., Aber, J. D.: 1999 a, Environ. Monit. Assess., in press.

Nadelhoffer, K. J., Downs, M. R., Fry, B.: 1999 b, Ecol. Appl. 9, 72-86.

Schleppi, P., Muller, N., Bucher, J. B.: 1998 a, J. For. Suisse 149, 1-15.

Schleppi, P., Muller, N., Feyen, H., Papritz, A., Bucher, J. B., Flühler H.: 1998 b, For. Ecol. Manage. 101, 177-185.

Schleppi, P., Muller, N., Edwards, P. J., Bucher, J. B.: 1999, Phyton, in press.

Tietema, A., Emmett, B. A., Gundersen, P., Kjønaas, O. J., Koopmans, C. J.: 1998, For. Ecol. Manage. 101, 19-27.

Wright, R. F., Rasmussen, L.: 1998, For. Ecol. Manage. 101, 1-7. 